\title{
Zooplankton resting egg banks in permanent and temporary tropical aquatic systems
}

\author{
Bancos de ovos de resistência do zooplâncton em sistemas \\ aquáticos tropicais permanentes e temporários
}

Luciana Rabelo Araújo ${ }^{1}$, Paloma Marinho Lopes ${ }^{1}$, Jayme Magalhães Santangelo², Ana Cristina Petry ${ }^{3}$ and Reinaldo Luiz Bozelli ${ }^{1}$

${ }^{1}$ Universidade Federal do Rio de Janeiro - UFRJ, Av. Carlos Chagas Filho, 373, CP 68020, CEP 21941-902, Rio de Janeiro, RJ, Brazil

e-mail: luciana.rabelo.araujo@gmail.com; paloma.marinho@gmail.com; bozelli@biologia.ufrj.br

${ }^{2}$ Universidade Federal Rural do Rio de Janeiro - UFRRJ,

Rod. BR 465, Km 07, CEP 23890-000, Seropédica, RJ, Brazil

e-mail: jaymems@gmail.com

${ }^{3}$ Núcleo em Ecologia e Desenvolvimento Sócio Ambiental de Macaé,

Universidade Federal do Rio de Janeiro - UFRJ, Campus UFRJ-Macaé Professor Aloísio Teixeira,

Av. São José do Barreto, 764, CEP 27971-550, Macaé, RJ, Brazil

e-mail: ac_petry@yahoo.com.br

\begin{abstract}
Aim: We evaluated zooplankton resting egg banks and active communities in five coastal lagoons and in five temporary pools, aiming to compare the active and the dormant communities in such environments. As they differ in hydroperiod, we expected that pools present richer resting egg banks in comparison to those found in lagoons. Methods: Zooplankton community was sampled twice in 2006 (lagoons) and in 2010 (pools) and resting egg banks were sampled once in December 2007 (lagoons) and in May 2010 (pools). Resting eggs were isolated from the sediment by applying the sugar flotation method. Results: In opposition to our expectation, species richness in the resting egg banks of pools did not differ from those of lagoons. Additionally, no difference was found between the active and the dormant zooplankton communities in each water body for both temporary and permanent environments. However, similarity between active and dormant communities was greater in permanent environments than it was in temporary environments. Conclusions: It seems that the diapause strategy observed in certain tropical zooplankton populations cannot be predicted based on the awareness of the environment type (permanent or temporary), since hatching cues may be species-specific.
\end{abstract}

Keywords: diapause, resting eggs, temporary pool, tropical zooplankton, coastal lagoon.

Resumo: Objetivo: Neste estudo avaliamos o banco de ovos de resistência e a comunidade ativa zooplanctônica de cinco lagoas costeiras permanentes e cinco poças temporárias com o intuito de comparar a comunidade ativa e dormente destes ambientes. Nós também supomos que, por diferirem no hidroperíodo, bancos de ovos de resistência de poças sáo mais ricos em espécies do que os de lagoas. Métodos: A comunidade zooplanctônica foi amostrada em duas ocasiōes em 2006 nas lagoas e em 2010 nas poças e o banco de ovos de resistência foi amostrado em dezembro de 2007 nas lagoas e em maio de 2010 nas poças. Resultados: Ao contrário de nossas expectativas, a riqueza do banco de ovos das poças não foi diferente das lagoas. Além disso, nenhuma diferença estatística na composição de espécies foi encontrada entre as comunidades ativa e dormente de um mesmo corpo d'água, tanto para ambientes permanentes quanto para temporários. Contudo, houve uma maior similaridade entre as comunidades ativas e dormentes dos ambientes permanentes do que dos temporários. Conclusóes: Nossos resultados permitem concluir que ambientes temporários e permanentes não diferem quanto à composição e riqueza de espécies de suas comunidades ativas e dormentes. Aparentemente, as estratégias de diapausa observadas em zooplâncton tropical não podem ser preditas apenas pelo tipo de ambiente (permanentes ou temporários), já que os fatores indutores de diapausa podem ser espécie-específicos.

Palavras-chave: diapausa, ovos de resistência, poças temporárias, zooplâncton tropical, lagoas costeiras. 


\section{Introduction}

Dormancy is one of the most conspicuous features among the zooplankton. The deterioration of environmental conditions is considered a decisive cue for stimulating the production of dormant stages (Brendonck and De Meester, 2003). Once produced, the resting eggs can accumulate and remain viable in the sediments for decades until the optimal conditions for hatching are recovered (Hairston, 1996; Caceres, 1998), allowing zooplankton populations to recolonize the same environment with hatchlings. Because not all eggs receive the triggers needed to hatch, the remaining viable eggs get stored in the sediments, so different generations' overlap may occur (García-Roger et al., 2006).

Timing is a key aspect for producing dormant stages, i.e. when initiating their production. The predictability of environmental conditions in aquatic systems including the length of the hydroperiod (e.g. permanent versus temporary environments) may lead the resting egg production cycle to meet three main specific patterns. For rotifers, for example, hydrologically more stable environments such as permanent aquatic waterbodies determine the polyphasic pattern prevalence. In such case, the resting eggs are produced systematically, but in low rates. In contrast to it, depending on the frequency of disturbances represented by desiccation of temporary waterbodies, the monophasic pattern is observed. In this pattern, a large fraction of the population has a single pulse for producing dormant stages, but a minor part of it keeps the parthenogenetic reproduction. Finally, as by the bang-bang pattern, the entire population triggers a massive resting eggs' production during a single period, and organisms disappear from the water column when sudden changes occur (Ricci, 2001). Therefore, drastic changes in environmental conditions can lead to premature or late changes in the prevailing mode of reproduction, reducing the contribution of certain genotypes and affecting population growth rates (Schröder and Gilbert, 2004).

In the northern region of the state of Rio de Janeiro - Brazil, there is a mosaic of coastal lagoons surrounded by several temporary pools that vary in their environmental conditions at both spatial and temporal scales. Pools and lagoons are very different systems regarding physical, chemical and ecological aspects, sustaining different zooplankton communities in the water column and in the resting egg banks. Regarding the zooplankton that colonizes these temporary environments, periodic droughts are considered a drastic disturbance
(Wellborn et al., 1996), and the production of dormant stages is viewed as an adaptation to deal with such adversity (García-Roger et al., 2005). Therefore, the zooplankton populations' ability to recolonize temporary aquatic environments after drought events might often depend on recruiting organisms from dormant stages (Brock et al., 2003).

According to such aspect, studies on resting egg banks are useful for featuring zooplankton communities in extreme environments, because they contain interesting information files about the species' composition. Moreover, comparative studies between temporary and permanent environments can expand the knowledge about such systems that may be highly associated to each other. Pools can act as a source or refuge for colonizers of permanent aquatic environments that undergo disturbances such as salinisation - a common issue in coastal lagoons (author's unpublished data).

Studies assessing resting egg banks in tropical systems - especially focused on rivers and lagoons - have substantially increased (Brandão et al., 2012; Iglesias et al., 2011; Santangelo et al., 2011a, b), but smaller and ephemeral environments, such as pools, have been scarcely considered. Due to a great variability in the hydroperiod, to complexity in the structure and to the composition of aquatic macrophytes as well as to the absence of top predators (Collinson et al., 1995, Scheffer et al., 2006), temporary ponds are propitious environments for the emergence of rare or endemic species (De Meester et al., 2005). Several studies have demonstrated how these small ecosystems contribute to the regional diversity (Oertli et al., 2002, Williams et al., 2004). The current study evaluated resting egg banks and active zooplankton communities in five coastal lagoons (herein named permanent environments) and five temporary pools (herein named temporary environments) in order to compare active and dormant communities from such environments. We expected temporary environments to hold richer resting egg banks than those found in permanent ones, considering that populations inhabiting pools are always facing more adverse periods such as desiccation.

\section{Material and Methods}

\subsection{Study area}

The current study was performed in five permanent coastal lagoons (Cabiúnas, Comprida, Carapebus, Garças and Imboassica) and five temporary pools (Pools 8, 9, 10, 11 and 12), located in the North of the state of Rio de Janeiro 
$\left(22^{\circ}-22^{\circ} 30^{\prime} \mathrm{S}\right.$ and $41^{\circ} 15^{\prime}-42^{\circ} \mathrm{W}-$ Figure 1$)$. Except for the Imboassica lagoon, located in the urban area of Macaé City, all studied environments are located within the boundaries of the Restinga de Jurubatiba National Park. These lagoons were formed and are maintained by a sandbar which dams small coastal rivers' flow, by upwelling groundwater and by rainfall storage. The lagoons Cabiúnas, Carapebus and Imboassica are subject to sewage discharge and/or temporary openings of their sandbar (Caliman et al., 2010), whilst the last factor may also lead to salinity increase due to hydrological connection with the ocean. On the other hand, pools are usually freshwater systems formed by rainfall storage, percolating groundwater, or eventually lagoon overflow. Throughout the drought period, however, these pools can get completely dry. All permanent and temporary environments are shallow (from 0.5 to $4.0 \mathrm{~m}$ ) and differ in limnological variables, especially in salinity (Table 1).

\subsection{Zooplankton community}

Samples were collected twice in each aquatic system, in 2006 (for permanent environments) and in 2010 (for temporary environments). The samples were collected either by filtering water (collected with a bucket - in the case of environments up to 1 meter depth) through a $50 \mu \mathrm{m}$ mesh plankton net or by directly taking vertical hauls with a $50 \mu \mathrm{m}$ plankton net (for deeper environments, see
Table 1 for depth data). Samples were immediately fixed with $4 \%$ formaldehyde. Zooplankters were identified as the lowest possible taxonomic units, and were counted either in a Sedgewick-Rafter chamber under a microscope (rotifers, nauplii, and cladocerans) or in open chambers under a stereomicroscope (copepodites and adult copepods). The entire samples content was analyzed in order to identify rare species.

\subsection{Resting egg bank}

Aiming to access the resting egg banks, the sediment was collected once, in December 2007 (for permanent environments) and in May 2010 (for temporary environments). The sampling was carried out with the aim of an $8 \mathrm{~cm}$ diameter sediment corer, being the first three centimeters of sediment removed, since such fraction corresponds to the active resting egg bank (Herzig, 1985; Caceres and Hairston, 1998). As lagoons present a larger area compared to pools, sediment was collected in the former at three different points, creating one single sample per lagoon. For the pools, one single sample was collected from their central area. After sampling, the sediment was kept in a dark plastic bag and stored in the dark at room temperature $\left(25-27^{\circ} \mathrm{C}\right)$.

Resting eggs were isolated from the sediment soon after sampling by the sugar flotation method (Onbé, 1978; Vandekerkhove et al., 2004). Sediment samples (100 g and $400 \mathrm{~g}$ of wet sediment for permanent and temporary environments,

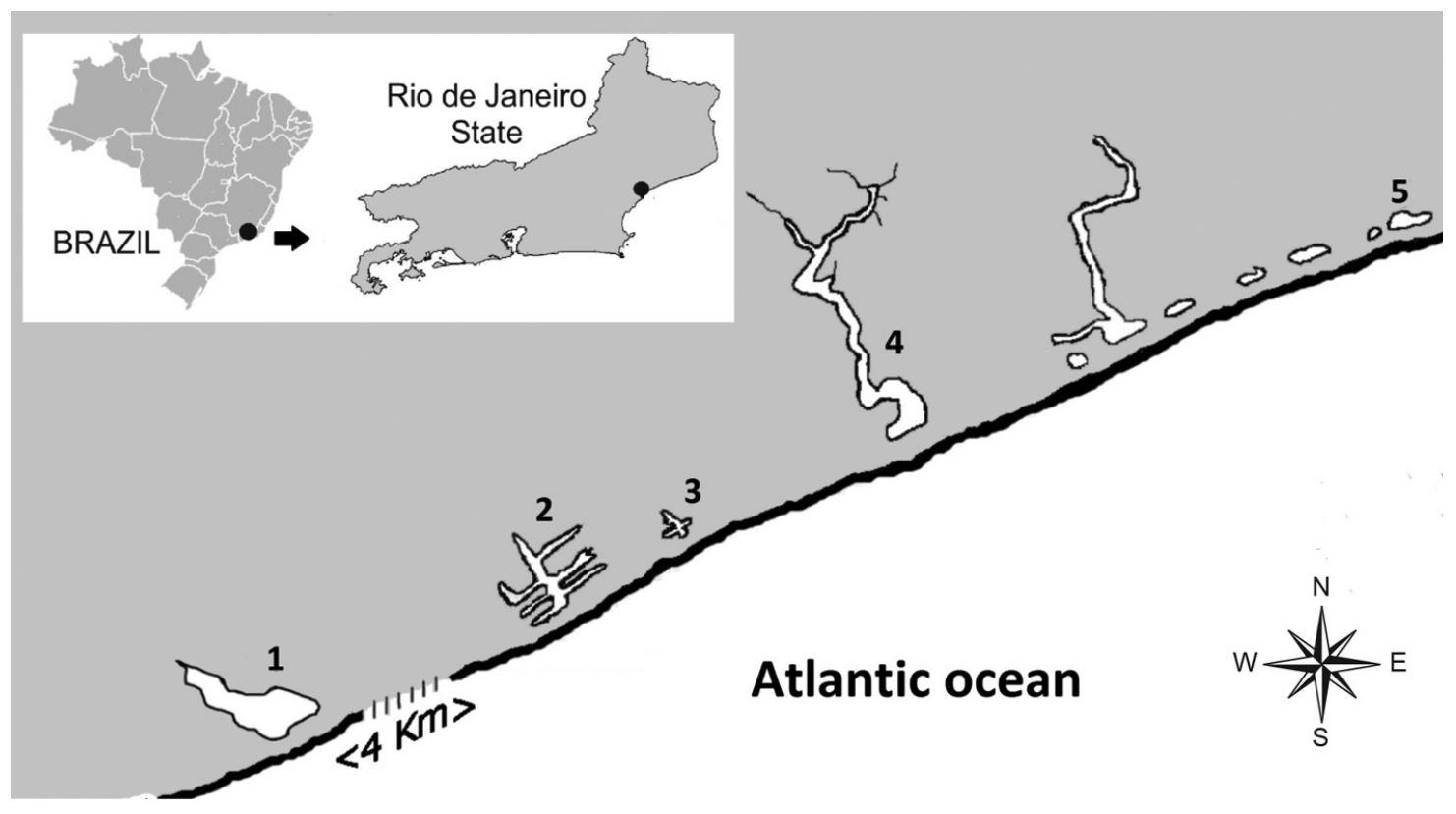

Figure 1. Geographical location of the five lagoons in Macaé, Rio de Janeiro (Brasil). 1- Imboassica; 2 - Cabiúnas; 3 - Comprida; 4 - Carapebus; 5 - Garças. 
Table 1. Limnological characteristics (mean \pm standard deviation) of the studied coastal lagoons and pools according to monthly surveys between 2002 and 2008 (Permanent; Caliman et al., 2010) and between 2010 and 2012 (Temporary).

\begin{tabular}{cccccc}
\hline System & Hydroperiod & Area $\left(\mathbf{k m}^{\mathbf{2}}\right)$ & Salinity & Temperature $\left({ }^{\circ} \mathbf{C}\right)$ & Depth $(\mathbf{m})$ \\
\hline Imboassica & Permanent & 2.60 & $3.52 \pm 4.22$ & $25.3 \pm 2.54$ & $1.36 \pm 0.44$ \\
Cabiunas & Permanent & 0.34 & $1.01 \pm 1.60$ & $25.5 \pm 2.62$ & $3.26 \pm 0.78$ \\
Comprida & Permanent & 0.11 & $0.13 \pm 0.06$ & $25.4 \pm 2.66$ & $2.38 \pm 0.65$ \\
Carapebus & Permanent & 4.11 & $5.31 \pm 3.72$ & $25.9 \pm 2.57$ & $3.20 \pm 0.65$ \\
Garças & Permanent & 0.21 & $31.22 \pm 28.75$ & $25.2 \pm 2.71$ & $0.85 \pm 0.34$ \\
Pool 08 & Temporary & $4,0 \times 10^{-5}$ & $0.19 \pm 0.10$ & $26.5 \pm 4.33$ & $0.51 \pm 0.17$ \\
Pool 09 & Temporary & $1,1 \times 10^{-4}$ & $0.17 \pm 0.11$ & $25.1 \pm 4.75$ & $0.14 \pm 0.10$ \\
Pool 10 & Temporary & $2,1 \times 10^{-3}$ & $1.01 \pm 1.57$ & $26.8 \pm 4.60$ & $0.30 \pm 0.15$ \\
Pool 11 & Temporary & $2,4 \times 10^{-3}$ & $7.76 \pm 10.60$ & $27.7 \pm 5.34$ & $0.22 \pm 0.13$ \\
Pool 12 & Temporary & $6,2 \times 10^{-4}$ & $0.12 \pm 0.04$ & $24.8 \pm 4.42$ & $0.09 \pm 0.16$ \\
\hline
\end{tabular}

respectively) were centrifuged at $2,700 \mathrm{rpm}$ for three minutes. After centrifugation, the supernatant was filtered on a $20-\mu \mathrm{m}$ size mesh net and washed with distilled water in order to remove the sugar. The concentrated material was incubated in small flasks containing $250 \mathrm{~mL}$ of an artificial medium (modified from Tollrian, 1993), resulting in five aquariums for the pools and five for the lagoons. The medium had $\mathrm{pH}$ values adjusted to 7.0 and salinity levels adjusted to 0.1 (freshwater) using a commercial sea salt (Sera Premium). Flasks were incubated at the temperature of $24^{\circ} \mathrm{C}$ and photoperiod of 12:12 h light-dark.

Samples were monitored daily, for twenty days. The water in each flask and the particles deposited on the bottom of it were filtered on a $20-\mu \mathrm{m}$ size mesh net and transferred to a petri dish, from which hatched individuals were removed, quantified and identified according to the lowest possible taxonomic category. The remaining material was put back in the flasks to be observed in the following day. Such procedure has been successfully used before, when resting eggs were hatched from a coastal lagoon (Santangelo et al., 2011b).

\subsection{Statistical analysis}

Rarefaction curves were used in order to compare species richness that would be found in a given number of individuals in resting egg banks of permanent and temporary environments. Therefore, we calculated the Mao Tao estimator to compare species richness of the ten samples based on random sub-sampling (999 randomizations) (Colwell, 2011). The analysis allows comparing species richness among sites (or data) that differ in sample size and sampling effort (Gotelli and Colwell, 2001). The Metric Multidimensional Scaling (MDS), based on Simpson's dissimilarity index, was used to display the active and dormant communities' structure in temporary and permanent environments. The Simpson's dissimilarity index is based on data presence or absence, but unlike the widely used Jaccard index, it is not affected by the samples' species richness (Baselga, 2010). A paired t-test using values from the main coordinate of MDS was used in order to compare species composition between active and dormant communities within lagoons and pools.

The rarefaction curves were performed using the software EstimateS v. 8.2 (Colwell, 2011), whilst MDS was performed in R 2.15.1 (R Development Core Team, 2011) using the 'vegan' package (Oksanen et al., 2011). The paired t-test was carried out in Statistica ${ }^{\text {TM }}$ v. 7.0 (StatSoft, 2007).

\section{Results}

The hatching experiment provided a total of 36 taxa, 26 of them rotifers, nine cladocerans and one calanoid copepod (Table 2). Among rotifers, 15 taxa were exclusively recorded in pools, showing prevalence of the Lecanidae family (11 species). Five species of Chydoridae (Cladocera) were also found in pools only (Table 2 ).

Permanent and temporary environments varied in regards to the species richness in the resting egg bank. Species richness in pools varied from 1 up to 18 species, while lagoons ranged from 1 up to 11 species (Figure 2). In general, environments with greater species richness in the water column also presented greater species richness in the dormant form, except for "pool 12", which presented the highest richness in the water column and the poorest resting egg bank (one species). The Carapebus lagoon was the only environment showing greater species richness in the resting egg bank than those found in the water column (Figure 2). However, rarefaction curves showed no significant differences 


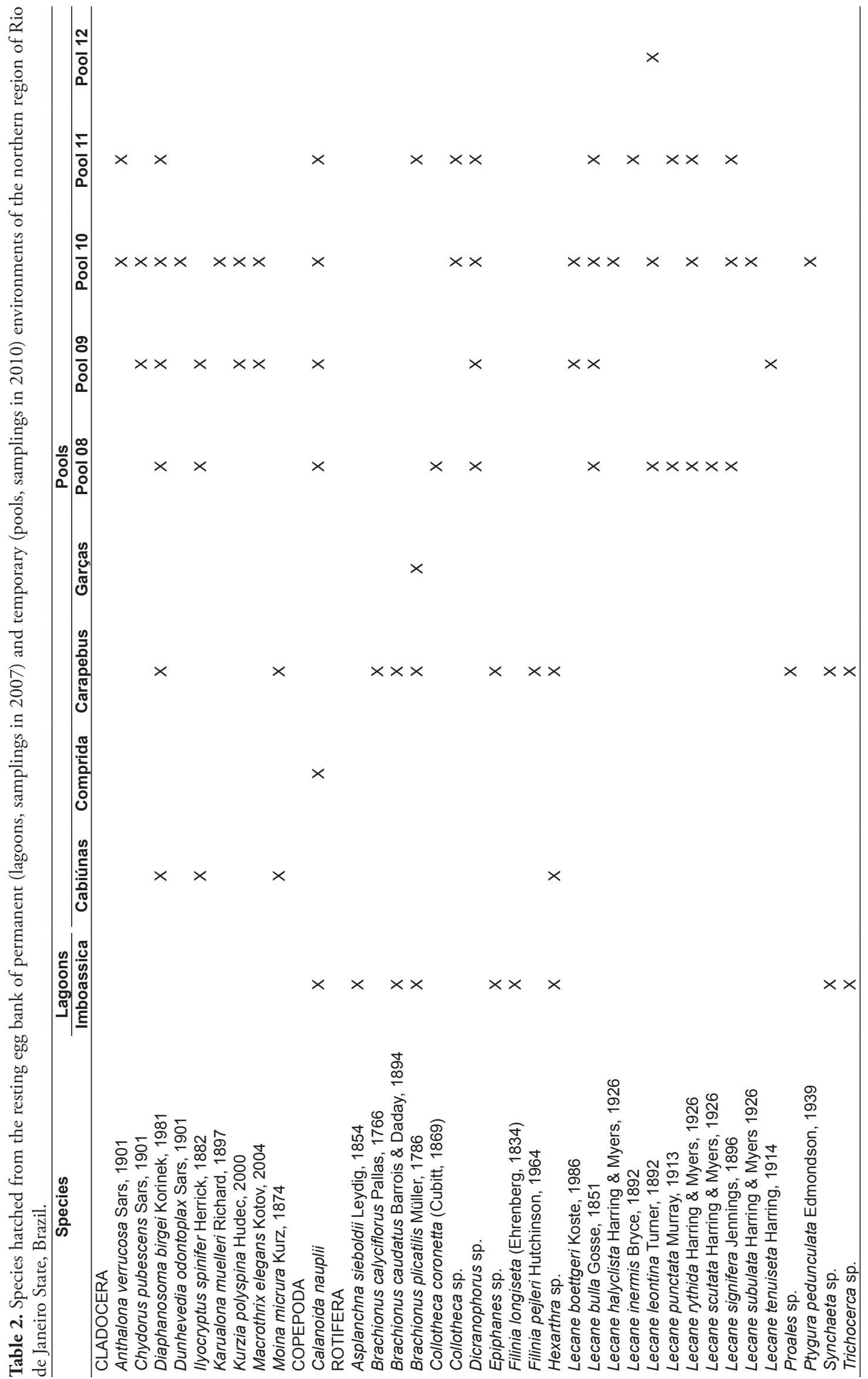




\section{Active}

\section{$\square$ Dormant}

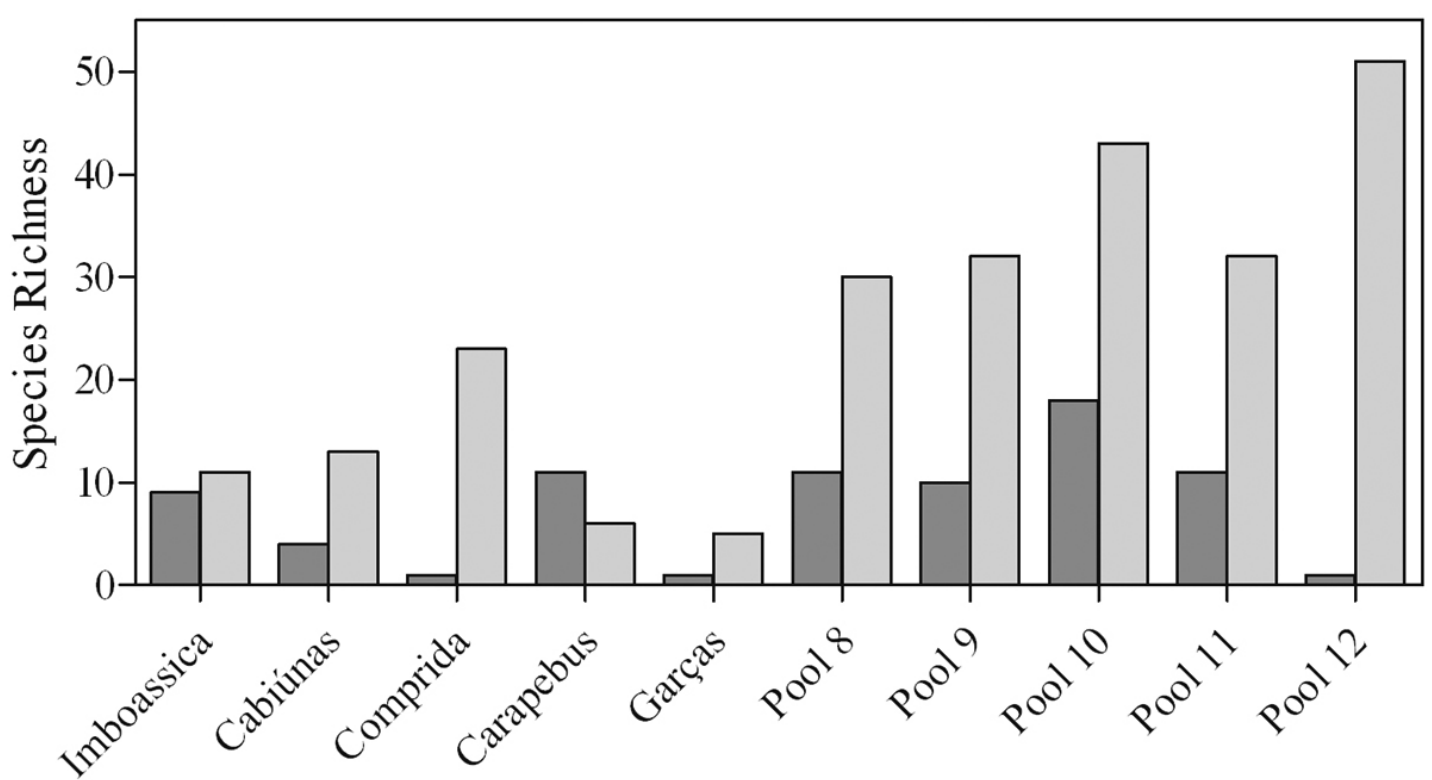

Figure 2. Species richness of resting egg banks and active zooplankton community of permanent (Imboassica, Cabiúnas, Comprida, Carapebus e Garças) and temporary (Pools 8, 9, 10, 11 and 12) environments. Resting egg banks from permanent and temporary systems were sampled in 2007 and 2010, respectively.

between pools and lagoons in the species richness of dormant communities (Figure 3).

The MDS grouped active zooplankton communities from pools, whilst dormant communities were more disperse (Figure 4b). A different pattern was observed in permanent environments (Figure 4a), where both active and dormant communities were located close to each other, suggesting that dormant and active communities are less variable in permanent lagoons. Significant differences in the composition of active and dormant communities were not observed for any type of system, both temporary $(\mathrm{t}=0.54$, $P=0.61)$ and permanent $(\mathrm{t}=2.31, P=0.08)$ environments.

\section{Discussion}

Our results demonstrated the presence of an active resting egg bank in all sampled permanent and temporary environments, but the egg banks' structure was not uniform among them. In fact, a high variability in resting egg banks has also been detected in a set of 26 Brazilian lakes (authors' unpublished data). Variability is likely associated to specific cues regarding induction of diapause in the field, as well as to different factors for its termination. Indeed, previous studies have shown that different cues are necessary in order to induce or terminate diapause, even within the same species (De Meester and De Jager, 1993; Caceres and Tessier, 2004; Gyllström and Hansson, 2004).

Resting egg banks are recognized as presenting a greater number of species in comparison to active communities (Duggan et al., 2002; Vandekerkhove et al., 2005; Mergeay et al., 2006). However, the current study showed the opposite pattern (except for the Carapebus lagoon), no matter the environment type. Such pattern might be also associated to the necessary cues needed to induce or to terminate diapause. It is known that not all populations are subjected to the needed stimulus to produce resting eggs, as well not all eggs found in the sediment are able to perceive the triggers that break the dormancy (De Meester and De Jager, 1993).

Moreover, different conditions needed for hatching under laboratory conditions may lead to underestimations of the species richness, since eggs seen in the sediment were not identified and quantified before the experiment. However, several studies have demonstrated that hatching experiments isolating resting eggs increase hatching success (Vandekerkhove et al., 2004) and they are effective when assessing zooplankton diversity. 


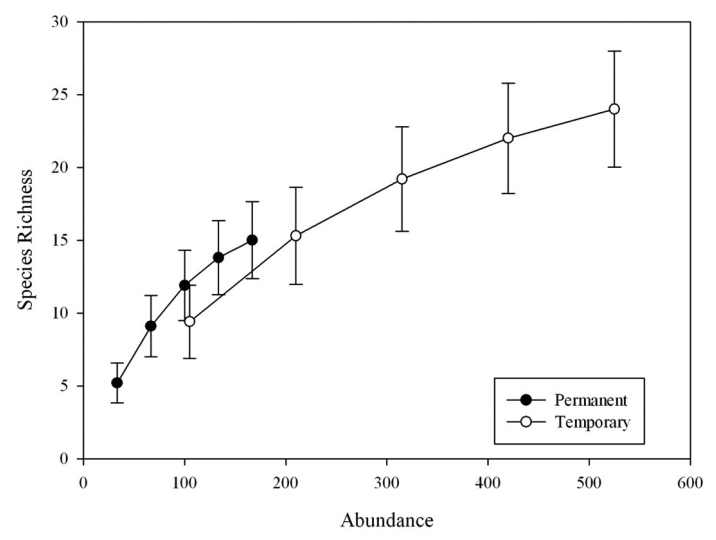

Figure 3. Species accumulation curves (mean $\pm 95 \%$ $\mathrm{CI}$ ) of resting egg banks from permanent and temporary environments based on the number of hatchlings. Permanent and temporary systems were sampled in 2007 and 2010, respectively.
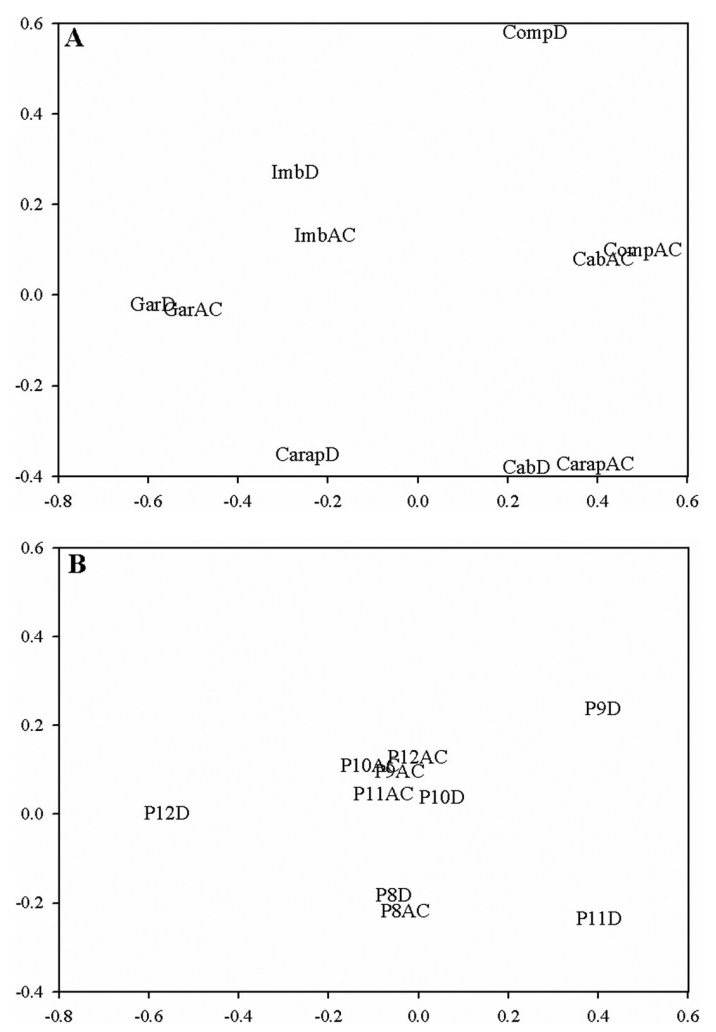

Figure 4. MDS graphic ordination of samples regarding the species zooplankton composition of the permanent (Figure A) and temporary environments (Figure B). $\mathrm{AC}=$ active community; $\mathrm{D}=$ resting egg banks. Permanent and temporary environments were sampled in 2007 and 2010, respectively.

Hence, it is possible that resting egg banks from the studied lagoons and pools are indeed impoverished. The current results corroborate a mesocosm experiment performed previously in these pools. The incubation of sediment in $100 \mathrm{~L}$ mesocosms and its exposition to natural conditions in the field also resulted in lower species richness when compared to those observed in the water column (authors' unpublished data). Indeed, several studies have shown that resting egg banks are relatively impoverished at least in Brazilian inland aquatic systems (Crispim and Watanabe, 2001; Maia-Barbosa et al., 2003; Panarelli et al., 2008; Santangelo et al., 2011b).

According to our results, temporary environments did not show a higher species richness than those found in permanent ones, refuting our primary hypothesis. It remains an open question: what are the factors responsible for diapause induction in tropical systems? At the studied tropical environments, temperature and photoperiod are probably less important than in the temperate ones, once such factors are less variable in tropical regions (Crispim and Watanabe, 2001). Seasonality in tropical aquatic environments is probably most closely related to rainfall and water level fluctuations, and this includes lentic environments of the Neotropical coastal plains. For many species, frequent flood and drought cycles are considered opportunities for hatching and producing resting eggs, especially in species with a very short life cycle (Waterkeyn et al., 2011). In fact, resting eggs are commonly found in temporary environments and represent an important form for populations' reestablishment (De Meester et al., 2002; Brock et al., 2003). The temporary environments covered throughout the current study suffer drastic water level reductions during the dry season, and often get completely dry. Water column reduction promotes high densities of organisms, which can induce diapause (Ricci, 2001; Schröder, 2005) and help explaining resting egg banks presence in the pools.

On the other hand, it has been reported that long-lasting inundation or reduction of the water level variability result in less environmental cues that are needed to trigger the production of resting eggs emergence (Golladay et al., 1997; Nielsen et al., 2000). It is important to note, however, that variations in the water level may lead to changes in several environmental variables that will likely stimulate resting eggs production in permanent environments. For example, changes in salinity might be frequent and intense in coastal lagoons (Esteves et al., 2008), possibly acting as cues to induce diapause, since few freshwater species are salt tolerant (Brock and Shiel, 1983; Sarma et al., 2006; Toruan, 2012). In general, resting eggs 
from many freshwater species tolerate salinity (Bailey et al., 2004; Waterkeyn et al., 2011), allowing populations' persistence in the long term. According to this study, some lagoons presented a consistent resting egg bank. In the Imboassica lagoon, for example, there were either detected one of the richest egg banks among the permanent environments and the smallest dissimilarity between the active and dormant communities.

Although resting eggs are capable to face unfavorable conditions (Brendonck and De Meester, 2003), there is a limit to such ability. A very frequent exposure to adverse conditions can lead to the egg bank's exhaustion (Waterkeyn et al., 2011) or even hamper its formation. In the present study, low species richness presented by the Garças lagoon - both for dormant and active communities - probably reflects intense changes in salinity throughout the last ten years (see the higher standard deviations in Table 1). Furthermore, other studies have suggested that diapause in permanent environments is more related to biotic factors such as competition and predation (Hansen and Hairston, 1998; Caceres and Tessier, 2004). It is known that, due their higher hydrological stability, permanent environments have a more mature zooplankton community, in which the strength of biotic interactions in structuring communities may be more effective than abiotic factors (Shurin, 2000). In addition, permanent environments such as lagoons may sustain a consistent planktivorous fish community, and several studies have shown an increase in the dormancy induction in zooplankton communities subjected to fish predation (Nielsen et al., 2000; Ślusarczyk, 2001; but see Santangelo et al., 2010, 2011c).

In conclusion, our results have shown that temporary and permanent environments did not differ in their dormant and active zooplankton composition and species richness. As diapause induction and termination may be very specific to species and populations, it seems that the diapause strategy adopted by certain zooplankton populations cannot be predicted just by the awareness that the environment they inhabit is temporary or permanent (Caceres and Tessier, 2004). Hence, to understand the diapause strategies of zooplankton from different tropical habitats, we must consider the scenarios that active and dormant zooplankters are exposed to, once the cues in tropical environments are still unclear.

\section{Acknowledgements}

We thank the staff of the Laboratorio de Limnologia da UFRJ and NUPEM/UFRJ for assistance during hatching experiments and field sampling. Financial support was provided by $\mathrm{CNPq}$ (314865/2009-8) and Petrobras. Fellowships to LR Araújo were provided by CAPES.

\section{References}

BAILEY, SA., DUGGAN, IC., VAN OVERDIJK, CDA., JOHENGEN, TH., REID, DF. and MACISAAC, HJ. 2004. Salinity tolerance of diapausing eggs of freshwater zooplankton. Freshwater Biology, vol. 49, p. 286-295. http://dx.doi.org/10.1111/j.13652427.2004.01185.x

BASELGA, A. 2010. Partitioning the turnover and nestedness components of beta diversity. Global Ecology and Biogeography, vol. 19, p. 134-143. http:// dx.doi.org/10.1111/j.1466-8238.2009.00490.x

BRANDÃO, LPM., FAJARDO, T., ESKINAZISANT'ANNA, E., BRITO, S. and MAIABARBOSA, P. 2012. Fluctuations of the population of Daphnia laevis Birge 1878: a six-year study in a tropical lake. Brazilian Journal Biology, vol. 72, no. 3, p. 479-487. PMid:22990818. http://dx.doi. org/10.1590/S1519-69842012000300010

BRENDONCK, L. and DE MEESTER, L. 2003. Egg banks in freshwater zooplankton: evolutionary and ecological archives in the sediment. Hydrobiologia, vol. 491, p. 65-84. http://dx.doi. org/10.1023/A:1024454905119

BROCK, MA. and SHIEL, RJ. 1983.The composition of aquatic communities in saline wetlands in Western Australia. Hydrobiologia, vol. 105, p. 77-84. http:// dx.doi.org/10.1007/BF00025178

BROCK, MA., NIELSEN, DL., SHIEL, RJ., GREEN, JD. and LANGLEY, JD. 2003. Drought and aquatic community resilience: the role of eggs and seeds in sediments of temporary wetlands. Freshwater Biology, vol. 48, p. 1207-1218. http://dx.doi.org/10.1046/ j.1365-2427.2003.01083.x

CACERES, CE. 1998. Interspecific variation in the abundance, production, and emergence of Daphnia diapausing eggs. Ecology, vol. 79, p. 1699-1710.

CACERES, CE. and HAIRSTON, NG. 1998. Benthicpelagic coupling in planktonic crustaceans: the role of the benthos. Archiv Fur Hydrobiologie, vol. 52, p. 163-174.

CACERES, CE. and TESSIER, AJ. 2004. To sink or swim: Variable diapause strategies among Daphnia species. Limnology and Oceanography, vol. 49, p. 1333-1340. http://dx.doi.org/10.4319/ lo.2004.49.4_part_2.1333

CALIMAN, A., CARNEIRO, LS., SANTANGELO, JM., GUARIENTO, RD., PIRES, APF., SUHETT, 
AL., QUESADO, LB., SCOFIELD, V., FONTE, ES., LOPES, PM., SANCHES, LF., AZEVEDO, FD., MARINHO, CC., BOZELLI, RL., ESTEVES, FA. and FARJALLA, VF. 2010. Temporal coherence among tropical coastal lagoons: a search for patterns and mechanisms. Brazilian Journal of Biology, vol. 70, p. 1-11. http://dx.doi.org/10.1590/S151969842010000400011

COLLINSON, NH., BIGGS, J., CORFIELD, A., HODSON, MJ., WALKER, D., WHITFIELD, M. and WILLIAMS, PJ. 1995. Temporary and permanent ponds: an assessment of the effects of drying out on the conservation value of aquatic macroinvertebrate communities. Biological Conservation, vol. 74, p. 125-134. http://dx.doi. org/10.1016/0006-3207(95)00021-U

COLWELL, RK. 2011. Estimates: Statistical Estimation of Species Richness and Shared Species from Samples. Version 8.2. User's Guide. Available from: <http:// purl.oclc.org/estimates>.

CRISPIM, MC. and WATANABE, T. 2001. What can dry reservoir sediments in a semi-arid region in Brazil tell us about Cladocera? Hydrobiologia, vol. 442, p. 101105. http://dx.doi.org/10.1023/A:1017550603022

DE MEESTER, L. and DE JAGER, H. 1993. Hatching of Daphnia Sexual Eggs .1. Intraspecific Differences in the Hatching Responses of Daphnia magna Eggs. Freshwater Biology, vol. 30, p. 219-226. http://dx.doi. org/10.1111/j.1365-2427.1993.tb00803.x

DE MEESTER, L., GÓMEZ, A., OKAMURA, B. and SCHWENK, K. 2002. The Monopolization Hypothesis and the dispersal-gene flow paradox in aquatic organisms. Acta Oecologica-International Journal of Ecology, vol. 23, p. 121-135. http://dx.doi. org/10.1016/S1146-609X(02)01145-1

DE MEESTER, L.; DECLERCK, S.; STOKS, R.; LOUETTE, G.; VAN DE MEUTTER, F.; DE BIE, T.; MICHELS, E. and BRENDONCK, L. 2005. Ponds and pools as model systems in conservation biology, ecology and evolutionary biology. Aquatic Conservation Marine and Freshwater Ecosystems, vol. 15, p. 715-725. http://dx.doi.org/10.1002/ aqc. 748

DUGGAN, IC., GREEN, JD. and SHIEL, RJ. 2002. Rotifer resting egg densities in lakes of different trophic state and their assessment using emergence and egg counts. Archiv Fur Hydrobiologie, vol. 153, p. 409-420.

ESTEVES, FA., CALIMAN, A., SANTANGELO, JM., GUARIENTO, RD., FARJALLA, VF. and BOZELLI, RL. 2008. Neotropical coastal lagoons: an appraisal of their biodiversity, functioning, threats and conservation management. Brazilian Journal of Biology, vol. 68, p. 631-637.

GARCÍA-ROGER, EM., CARMONA, MJ. and SERRA, M. 2005. Deterioration patterns in diapausing egg banks of Brachionus (Müller, 1786) rotifer species.
Journal of Experimental Marine Biology and Ecology, vol. 314, p. 149-161. http://dx.doi.org/10.1016/j. jembe.2004.08.023

GARCÍA-ROGER, EM., CARMONA, MJ. and SERRA, M. 2006. Patterns in rotifer diapausing egg banks: Density and viability. Journal of Experimental Marine Biology and Ecology, vol. 336, p. 198-210. http://dx.doi.org/10.1016/j.jembe.2006.05.009

GOLLADAY, SW., TAYLOR, BW. and PALIK, BJ. 1997. Invertebrate communities of forested limesink wetlands in southwest Georgia, USA: habitat use and influence of extended inundation. Wetlands, vol. 17, p. 383-393. http://dx.doi.org/10.1007/BF03161428

GOTELLI, NJ. and COLWELL, RK. 2001. Quantifying biodiversity: procedures and pitfalls in the measurement and comparison of species richness. Ecology Letters, vol. 4, p. 379-391. http://dx.doi. org/10.1046/j.1461-0248.2001.00230.x

GYLLSTRÖM, M. and HANSSON, LA. 2004. Dormancy in freshwater zooplankton: Induction, termination and the importance of benthic-pelagic coupling. Aquatic Sciences, vol. 66, p. 274-295. http://dx.doi.org/10.1007/s00027-004-0712-y

HAIRSTON, NG. 1996. Zooplankton egg banks as biotic reservoirs in changing environments. Limnology and Oceanography, vol. 41, p. 1087-1092. http://dx.doi.org/10.4319/lo.1996.41.5.1087

HANSEN, AM. and HAIRSTON, NG. 1998. Food limitation in a wild cyclopoid copepod population: direct and indirect life history responses. Oecologia, vol. 115, p. 320-330. http://dx.doi.org/10.1007/ s004420050523

HERZIG, A., 1985. Resting eggs - a significant stage in the life cycle of crustaceans Leptodora kindti and Bythotrephes longimanus. Verhandlungen des Internationalen Verein Limnologie, vol. 22, p. 30883098.

IGLESIAS, C., MAZZEO, N., MEERHOFF, M., LACEROT, G., CLEMENTE, JM., SCASSO, F., KRUK, C., GOYENOLA, G., GARCÍA-ALONSO, J., AMSINCK, SL., PAGGI, JC., JOSÉ DE PAGGI, S. and JEPPESEN, E. 2011. High predation is of key importance for dominance of small-bodied zooplankton in warm shallow lakes: evidence from lakes, fish exclosures and surface sediments. Hydrobiologia, vol. 667, p. 133-147. http://dx.doi. org/10.1007/s10750-011-0645-0

MAIA-BARBOSA, PM., ESKINAZI-SANT'ANNA, EM., VALADARES, CF. and PESSOA, GCD. 2003. The resting eggs of zooplankton from a tropical, eutrophic reservoir (Pampulha Reservoir, south-east Brazil). Lakes \& Reservoirs: Research and Management, vol. 8, p. 269-275. http://dx.doi.org/10.1111/j.14401770.2003.00229.x

MERGEAY, J., DECLERCK, S., VERSCHUREN, D. and DE MEESTER, L. 2006. Daphnia community 
analysis in shallow Kenyan lakes and ponds using dormant eggs in surface sediments. Freshwater Biology, vol. 51, p. 399-411. http://dx.doi.org/10.1111/ j.1365-2427.2005.01494.x

NIELSEN, DL., SMITH, FJ., HILLMAN, TJ. and SHIEL, RJ. 2000. Impact of water regime and fish predation on zooplankton resting egg production and emergence. Journal of Plankton Research, vol. 22, no. 3, p. 433-446. http://dx.doi.org/10.1093/ plankt/22.3.433

OERTLI, B., JOYE, DA., CASTELLA, E., JUGE, R., CAMBIN, D. and LACHAVANNE, JB. 2002. Does size matter? The relationship between pond area and biodiversity. Biological Conservation, vol. 104, p. 59-70. http://dx.doi.org/10.1016/S00063207(01)00154-9

OKSANEN, J., BLANCHET, FG., KINDT, R., LEGENDRE, P., O'HARA, RB., SIMPSON, GL., SOLYMOS, P., STEVENS, MHH. and WAGNER, H. 2011. vegan: Community Ecology Package. $R$ package version 1.17-9. Available from: <http:// CRAN.R-project.org/package $=$ vegan $>$.

ONBÉ, T., 1978. Sugar flotation method for sorting the resting eggs of marine cladocerans and copepods from sea-bottom sediment. Bulletin of the Japanese Society of Scientific Fisheries, vol. 44, p. 1411-1411.

PANARELLI, EA., CASANOVA, SMC. and HENRY, R. 2008. The role of resting eggs in the recovery of zooplankton community in a marginal lake of the Paranapanema River (São Paulo, Brazil), after a long drought period. Acta Limnologica Brasiliensia, vol. 20, p. 73-88.

R Development Core Team. 2011. R: A Language and Environment for Statistical Computing. Vienna: R Foundation for Statistical Computing. Available from: <http://www.R-project.org/>.

RICCI, C. 2001. Dormancy patterns in rotifers. Hydrobiologia, vol. 446, p. 1-11. http://dx.doi. org/10.1023/A:1017548418201

SANTANGELO, JM., BOZELLI, RL., ESTEVES, FA. and TOLLRIAN, R. 2010. Predation cues do not affect the induction and termination of diapause in small-bodied cladocerans. Freshwater Biology, vol. 55, p. 1577-1586. http://dx.doi.org/10.1111/j.13652427.2009.02389.x

SANTANGELO, JM., ARAÚJO, LR., ESTEVES, FA., MANCA, M. and BOZELLI, RL. 2011a. Method for hatching resting eggs from tropical zooplankton: effects of drying or exposing to low temperatures before incubation. Acta Limnologica Brasiliensia, vol. 23, p. 42-47. http://dx.doi.org/10.4322/ actalb.2011.017

SANTANGELO, JM., ESTEVES, FA., MANCA, M. and BOZELLI, RL. 2011b. Abundance, composition and spatial variation in the egg bank of a tropical zooplankton community. Studies on Neotropical
Fauna and Environment, vol. 46, p. 225-232. http:// dx.doi.org/10.1080/01650521.2011.632672

SANTANGELO, JM., ESTEVES, FA., TOLLRIAN, R. and BOZELLI, RL. 2011c. A small-bodied cladoceran (Moina micrura) reacts more strongly to vertebrate than invertebrate predators: a transgenerational life-table approach. Journal of Plankton Research, vol. 33, p. 1767-1772. http://dx.doi.org/10.1093/ plankt/fbr063

SARMA, S., NANDINI, S., MORALES-VENTURA, J., DELGADO-MARTÍNEZ, I. and GONZÁLEZVALVERDE, L. 2006. Effects of $\mathrm{NaCl}$ salinity on the population dynamics of freshwater zooplankton (rotifers and cladocerans). Aquatic Ecology, vol. 40, p. 349-360. http://dx.doi.org/10.1007/s10452006-9039-1

SCHEFFER, M., VAN GEEST, GJ., ZIMMER, K., JEPPESEN, E., SØNDERGAARD, M., BUTLER, MG., HANSON, MA., DECLERCK, S. and DE MEESTER, L. 2006. Small habitat size and isolation can promote species richness: second-order effects on biodiversity in shallow lakes and ponds. Oikos, vol. 112, p. 227-231. http://dx.doi.org/10.1111/ j.0030-1299.2006.14145.x

SCHRÖDER, T. 2005. Diapause in monogonont rotifers. Hydrobiologia, vol. 546, p. 291-306. http:// dx.doi.org/10.1007/s10750-005-4235-x

SCHRÖDER, T. and GILBERT, JJ. 2004. Transgenerational plasticity for sexual reproduction and diapause in the life cycle of monogonont rotifers: intraclonal, intraspecific and interspecific variation in the response to crowding. Functional Ecology, vol. 18, p. 458-466. http://dx.doi.org/10.1111/j.02698463.2004.00854.x

SHURIN, JB. 2000. Dispersal limitation, invasion resistance, and the structure of pond zooplankton communities. Ecology, vol. 81, p. 3074-3086. http:// dx.doi.org/10.1890/0012-9658(2000)081[3074:DL IRAT]2.0.CO;2

ŚLUSARCZYK, M. 2001. Food threshold for diapause in Daphnia under the threat of fish predation. Ecology, vol. 82, p. 1089-1096.

StatSoft. 2007. STATISTICA (data analysis software system), version 8.0. Available from: < www.statsoft. com>

TOLLRIAN, R. 1993. Neckteeth formation in Daphniapulex as an example of continuous phenotypic plasticity - morphological effects of Chaoborus kairomone concentration and their quantification. Journal of Plankton Research, vol. 15, p. 1309-1318. http://dx.doi.org/10.1093/plankt/15.11.1309

TORUAN, RL. 2012. Zooplankton community emerging from fresh and saline wetlands. Ecohydrology \& Hydrobiology, vol. 12, p. 53-63. http://dx.doi. org/10.2478/v10104-012-0003-5 
VANDEKERKHOVE, J., NIESSEN, B., DECLERCK, S., JEPPESEN, E., PORCUNA, J. M. C., BRENDONCK, L. and DE MEESTER, L. 2004. Hatching rate and hatching success with and without isolation of zooplankton resting stages. Hydrobiologia, vol. 526, p. 235-241. http://dx.doi.org/10.1023/ B:HYDR.0000041598.68424.fc

VANDEKERKHOVE, J., DECLERCK, S., BRENDONCK, L., CONDE-PORCUNA, JM., JEPPESEN, E., JOHANSSON, LS. and DE MEESTER, L. 2005. Uncovering hidden species: hatching diapausing eggs for the analysis of cladoceran species richness. Limnology and Oceanography-Methods, vol. 3, p. 399-407. http:// dx.doi.org/10.4319/lom.2005.3.399

WATERKEYN, A., VANSCHOENWINKEL, B., VERCAMPT, H., GRILLAS, P. and BRENDONCK,
L. 2011. Long-term effects of salinity and disturbance regime on active and dormant crustacean communities. Limnology and Oceanography, vol. 56, no. 3, p. 1008-1022. http://dx.doi.org/10.4319/ lo.2011.56.3.1008

WELLBORN, GA., SKELLY, DK. and WERNER, EE. 1996. Mechanisms creating community structure across a freshwater habitat gradient. Annual Review of Ecology and Systematics, vol. 27, p. 337-363. http:// dx.doi.org/10.1146/annurev.ecolsys.27.1.337

WILLIAMS, P., WHITFIELD, M., BIGGS, J., BRAY, S., FOX, G., NICOLET, P. and SEAR, D. 2004. Comparative biodiversity of rivers, streams, ditches and ponds in an agricultural landscape in Southern England. Biological Conservation, vol. 115, p. 329-341. http://dx.doi.org/10.1016/S00063207(03)00153-8

Received: 05 May 2013

Accepted: 04 October 2013 